\title{
CORRIGENDUM
}

\section{SOME GENERATING FUNCTIONS OF MODIFIED BESSEL POLYNOMIALS FROM THE VIEW POINT OF LIE GROUP}

\author{
ASIT KUMAR CHONGDAR \\ Department of Mathematics \\ Bangabasi Engineering College \\ 19 Scott Lane, \\ Calcutta - 700009, India
}

There were some errors in the above paper (which appeared in Vol. 7, No. 4, 1984, pp 823-825). These errors are corrected as follows:

Replace the left hand side of equation (1.3) on page 823 with

$$
(1-x w)^{1-\alpha} e^{B w} G\left(\frac{x}{1-x w}, w z\right) ; \quad \text { and }
$$

Replace the right hand side of the last equation on page 824 with

$$
\sum_{m=0}^{n} \frac{(\beta z)^{m}}{(m !)^{2}}
$$

\section{THIRTY-NINE PERFECT NUMBERS AND THEIR DIVISORS}

\section{SYED ASADULLA}

Department of Mathematics and Computing Sciences

St. Francis Xavier University

Antigonish, Nova Scotia, B2G 1C0, Canada

There were some errors in the above paper which appeared in Vol. 9, No. 1, 1986 pp. 205-206. These errors are corrected as follows:

Replace the word Thirty-nine with Thirty in the title of the paper and on 1 ine 8 (from the top) page 206. 


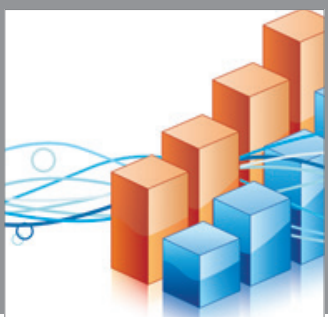

Advances in

Operations Research

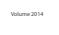

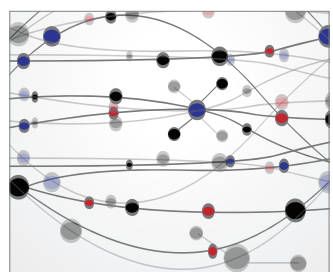

\section{The Scientific} World Journal
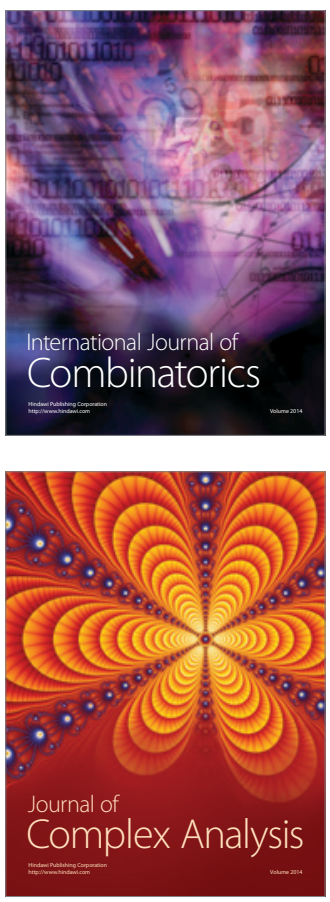

International Journal of

Mathematics and

Mathematical

Sciences
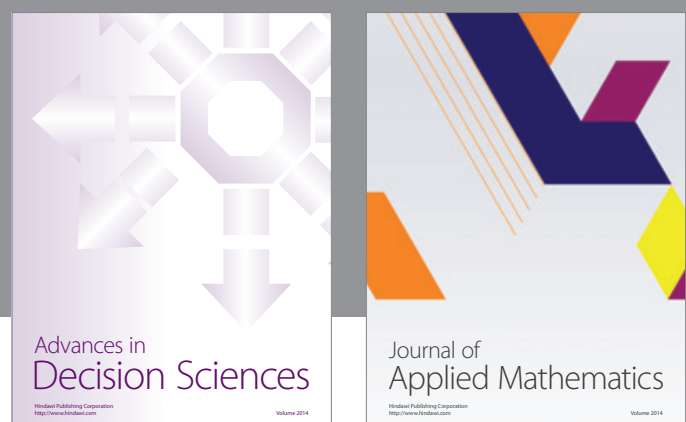

Journal of

Applied Mathematics
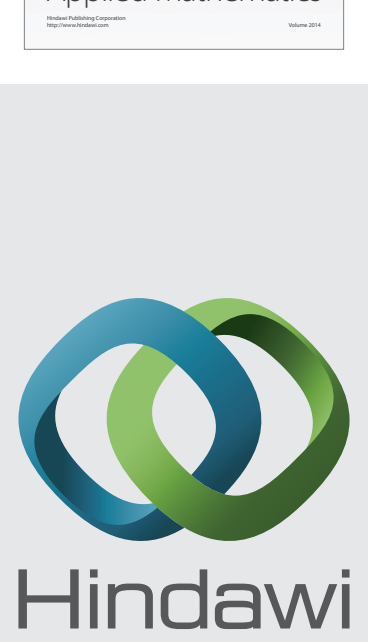

Submit your manuscripts at http://www.hindawi.com
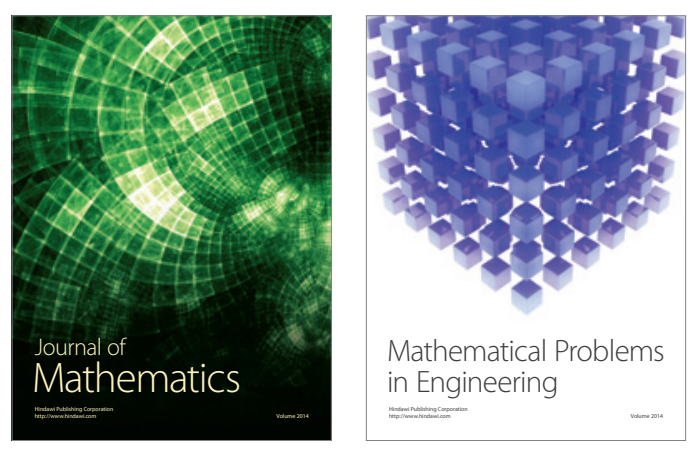

Mathematical Problems in Engineering
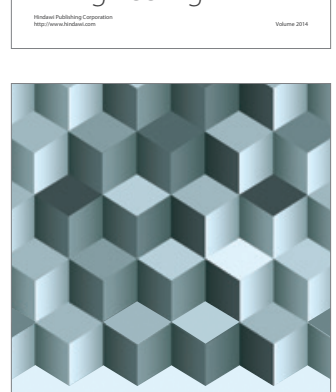

Journal of

Function Spaces
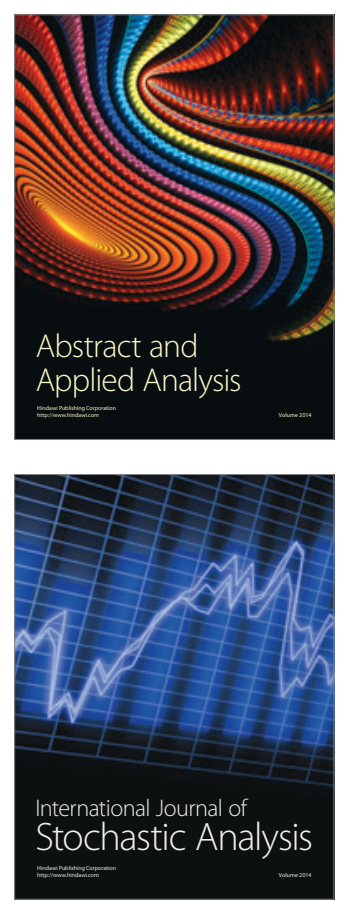

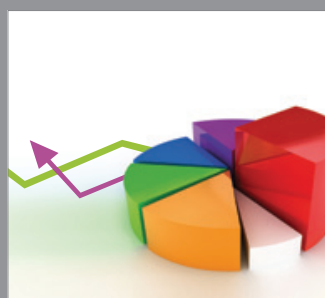

ournal of

Probability and Statistics

Promensencen
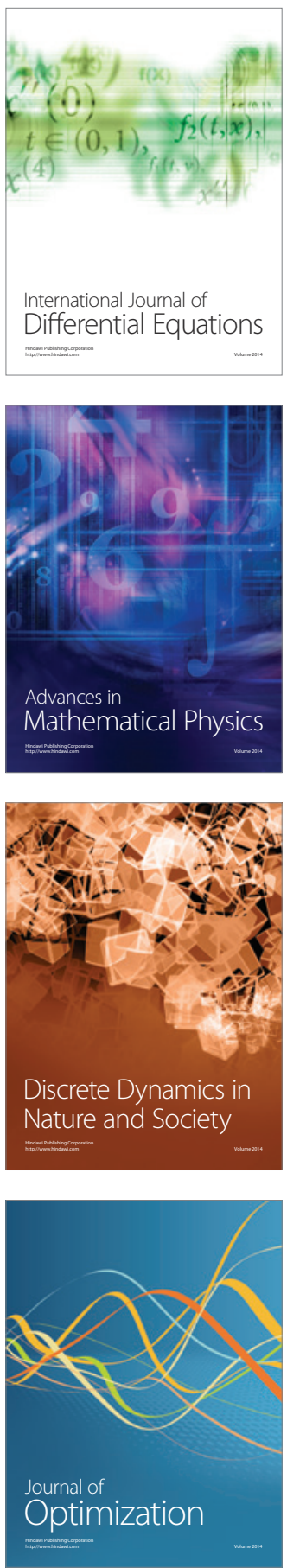